\title{
Evaluation of Anthelmintic Activity of Butea frondosa (Koeing ex Roxb.) Seeds Extracts Against Benzimidazole Resistant Caprine Gastrointestinal Nematodes
}

\author{
Rupanjali Saiyam ${ }^{1}$, Giridhari Das ${ }^{1 *}$, Suman Kumar ${ }^{1}$, Rupesh Verma ${ }^{1}$, Kshemankar Shrman ${ }^{2}$, \\ Shashi Pradhan ${ }^{3}$, Kusum Lata ${ }^{1}$ and Siddhant Bendigeri ${ }^{1}$ \\ ${ }^{1}$ Department of Veterinary Parasitology, College of Veterinary Science \& A.H., NDVSU, Jabalpur, Madhya Pradesh, INDIA \\ ${ }^{2}$ Department of Veterinary Pharmacology and Toxicology, College of Veterinary Science \& A.H., NDVSU, Jabalpur, \\ Madhya Pradesh, INDIA \\ ${ }^{3}$ Department of Veterinary Medicine, College of Veterinary Science \& A.H., NDVSU, Jabalpur, Madhya Pradesh, INDIA \\ *Corresponding author: G Das; E-mail: gdasvetpara@gmail.com
}

Received: 03 Jan., 2021

Revised: 28 Jan., 2021

Accepted: 30 Jan., 2021

\begin{abstract}
The present investigation was carried out to evaluate the anthelmintic efficacy of crude aqueous and methanolic extract of Butea frondosa seeds extracts against benzimidazole resistant gastrointestinal nematodes of goats through in vitro and in vivo methods. In vitro investigation was carried out by egg hatch assay (EHA), larval paralysis test (LPT) and adult mortality test (AMT) against different stages of gastrointestinal nematodes whereas, in vivo by faecal egg count reduction (FECR) test in goats naturally infected with benzimidazole resistant GI nematodes. In in vitro trial, methanolic extract showed better $\mathrm{ED}_{50}$ in egg hatch assay and larval paralysis test as compared to aqueous extract. Moreover, in adult mortality tests, the methanolic extract gave better average corrected mortality as compared to aqueous extract. In vivo results revealed that the group treated with methanolic extracts showed the significant reduction $(\mathrm{p}<0.05)$ on $21^{\text {st }}$ day whereas, the group treated with aqueous extract showed the highest and significant reduction $(\mathrm{p}<0.01)$ on $14^{\text {th }}$ day. The results of both in vitro and in vivo trials suggest that $B$. frondosa possess anthelmintic activity and could be considered as one of the alternatives to the chemical anthelmintic.
\end{abstract}

\section{HIGHLIGHTS}

(0 The methanolic and aqueous extracts of $B$. frondosa possess anthelmintic activity against the benzimidazole resistant GI nematodes of goats.

(0 Methanolic extract showed better efficacy as compare to aqueous extract.

Keywords: Butea frondosa, Benzimidazole resistance, Anthelmintic activity, Gastrointestinal nematodes, Goat

The era of modern anthelmintics began in the mid- $20^{\text {th }}$ century, with the introduction of phenothiazine and piperazine. These anthelmintics have been extensively used by veterinarians and livestock producers to control parasites either by drenching or injecting them into cattle, buffalo, sheep and goats (Soulsby, 1982). However, due to indiscriminate uses, the worms started developing resistance against anthelmintics. Anthelmintic resistance in GI nematodes, particularly high prevalence of multidrug resistance, has been reported among the three broadspectrum and narrow-spectrum anthelmintic drugs from several countries across the world (Verma et al., 2018).
Although the matter is more rampant in small ruminants, reports have also been documented globally from cattle, horses and pigs (Temesgen and Tone, 2019; Vohra et al., 2019). This has triggered the evaluation of conventionally used plants for their anthelmintic properties (Tandon et al., 2011). B. frondosa popularly referred to as 'flame of

How to cite this article: Saiyam, R., Das, G., Kumar, S., Verma, R. Shrman, K., Pradhan, S., Lata, K. and Bendigeri, S. (2021). Evaluation of anthelmintic activity of Butea frondosa (Koeing ex Roxb.) seeds extracts against benzimidazole resistant caprine gastrointestinal nematodes. $J$ Anim. Res., 11(1): 33-39.

Source of Support: None; Conflict of Interest: None 
the forest', widely found in tropical and sub-tropical parts of the Indian Subcontinents and Southeast Asia (Patil et al., 2006). The seed of $B$. frondosa has exhibited excellent anthelmintic property especially for roundworms (Iqbal et al., 2006; Sant et al., 2014; Singh et al., 2015). Keeping in view, the study was planned to evaluate the anthelmintic activity of $B$. frondos $a$ seeds extracts against benzimidazole resistant GI nematodes of goats in order to counter the anthelmintic resistance in livestock.

\section{MATERIALS AND METHODS}

\section{Location of work}

The study was carried out in the Department of Veterinary Parasitology and institutional goat farm maintained in semi intensive conditions at Amanala, College of Veterinary Science \& Animal Husbandry, Nanaji Deshmukh Veterinary Science University (NDVSU), Jabalpur district which is located in agro-climatic zone III $\left(23^{\circ} 1079 \mathrm{~N}, 79^{\circ} 56\right.$ and $\mathrm{E}$ and $\left.411 \mathrm{~m} \mathrm{MSL}\right)$ of the state of Madhya Pradesh, India. The proposed work was carried on the goat farm, which already has been reported to have benzimidazole resistance in gastrointestinal nematodes (Das et al., 2015; Dixit et al., 2017).

\section{Collection and extract preparation of plant material}

Seeds of $B$. frondosa (Koeing ex Roxb.) were collected from in and around Jabalpur (M.P). The plant specimen was identified and authenticated by Forest Botany \& Eco Division, State Forest Research Institute, Jabalpur with collection number 16342 and registration number 8052 . Seeds were cleaned, washed and air dried followed by drying in an incubator at $40^{\circ} \mathrm{C}$. The dried seeds were ground in an electrical mixer grinder to make powder and stored in airtight containers for the preparation of extracts. Both aqueous and methanolic extracts were prepared as per the procedure as describe by Kanojiya et al. (2015a).

\section{In-vitro evaluation of anthelmintic activity of $B$. frondosa extracts}

\section{Egg hatch assay}

The egg hatch assay was performed as per the method described by Coles et al. (1992) with slight modifications. The number of egg were estimated per $\mathrm{ml}$ and adjusted to $100-150$ eggs/200 $\mu 1.200 \mu \mathrm{l}$ of fresh egg suspension were placed in each well containing $1 \mathrm{ml}$ extract of different concentration ranging from $0.156 \%(1.56 \mathrm{mg} / \mathrm{ml})-10 \%$ $(100 \mathrm{mg} / \mathrm{ml})$ in a multi-well plate while the control wellreceived PBS. The volume of each well was made up to $2 \mathrm{ml}$ by adding $800 \mu \mathrm{l}$ of distilled water. The plates were incubated under humidified conditions at $27^{\circ} \mathrm{C}$ for $48 \mathrm{hrs}$ and later, a drop of Lugol's iodine solution was added to every well to prevent further hatching. Hatched larvae and un-hatched eggs were then counted under a light microscope.

\section{Larval paralysis test}

Larvae were obtained by culturing the per-rectally collected faecal samples from the goat of the farm (Sloss et al., 1997). $100 \mu 1$ containing 100-150 live larvae were exposed to different concentration of extracts ranging from $0.156 \%(1.56 \mathrm{mg} / \mathrm{ml})-10 \%(100 \mathrm{mg} / \mathrm{ml})$ in the multi-well plates. After $24 \mathrm{hrs}$, live (motile) and dead larvae were counted.

\section{Adult mortality test}

Adult Haemonchus contortus worms were procured from the abomasii of goats after slaughter or during postmortem. The motile adult worms were cleaned with lukewarm normal saline and transferred in a beaker containing phosphate buffer saline (PBS) and were kept in an incubator at $37^{\circ} \mathrm{C}$ until required for the experiment on the same day. For AMT, ten adult $H$. contortus were taken in small Petri dishes having different dilutions of extracts in PBS ranging from $0.156 \%(1.56 \mathrm{mg} / \mathrm{ml})-10 \%(100$ $\mathrm{mg} / \mathrm{ml})$, while control Petri dish received only PBS. The total volume of each Petri dish was kept at $5 \mathrm{ml}$. It was then incubated at $37 \pm 1^{\circ} \mathrm{C}$ for $24 \mathrm{hrs}$ and the number of live and dead adult worms were counted at 1, 2, 4, 6, 12, 18 and $24 \mathrm{hrs}$ of exposure as described by Sujon et al. (2008).

$\%$ corrected mortality $=$

Total mortality - mortality in the control group Total mortality 


\section{In-vivo evaluation of anthelmintic efficacy of $B$. frondosa}

\section{Ethical approval}

This study was approved by Institutional Animal Ethical Committee, College of Veterinary Science and Animal Husbandry (NDVSU), Jabalpur (M.P) keeping in mind the guidelines of CPCSEA (Certificate No: 115/IAEC/ VETY/2017).

\section{Selection and treatment of animals}

The goats having EPG $\geq 300$ were selected and divided into 3 groups with 8 goats in each. Group-I and II were treated with aqueous and methanolic extract of $B$. frondosa, respectively at the rate of $100 \mathrm{mg} / \mathrm{kg} \mathrm{b}$. wt. orally on day $0,3^{\text {rd }}$ and $7^{\text {th }}$ whereas, Group III was kept as an untreated control.

\section{Faecal egg count reduction test (FECRT)}

As per the standard protocol, faecal samples were collected from the rectum of goats of treated and control groups individually on the day 0 (pre-treatment), the day 7,14 , 21 and 28 (post-treatment). The intensity of infection was determined by the modified McMaster technique (Sloss et al., 1997). The faecal egg count data were analyzed by faecal egg count reduction test (FECRT \%) for the anthelmintic efficacy of the extracts on a particular day using the following formula given by Dash et al., 1988 .

$\%$ efficacy $=$

\section{EPG of control group - EPG of treated group} EPG of control group

\section{Statistical analysis}

The data of in-vitro test viz. Egg Hatch Assay and Larval Paralysis Test were analyzed by log probit analysis for calculation of $\mathrm{ED}_{50}$ Value (Finney, 1971). However, invivo anthelmintic efficacy was determined by FECRT $\%$ and significant effect was determined by students't' test (Snedecor and Cochran, 1994).

\section{RESULTS AND DISCUSSION}

\section{In-vitro evaluation of anthelmintic activity}

\section{Egg hatch Assay}

The results revealed that egg hatch percentage at the concentration of $10 \%(100 \mathrm{mg} / \mathrm{ml})$ for aqueous and methanolic extract was 1.29 and $1.00 \%$ with corrected egg hatch percentage 2.61 and $1.33 \%$, respectively. Whereas, egg hatch percentage of aqueous extract at concentration $5 \%$ (50 mg/ml), 2.5\% (25 mg/ml), 0.625\% (6.25 mg/ml), $0.3125 \%(3.125 \mathrm{mg} / \mathrm{ml})$ and $0.156 \%(1.56 \%)$ were 8.91 , $15.77,33.11,47.10,45.19,77.74$ and $98.68 \%$, respectively with corrected egg hatch percentage 10.23, 17.09, 34.43, $48.41,46.51$ and $79.06 \%$, respectively. Whereas, egg hatch percentage of methanolic extract at concentration $5 \%(50 \mathrm{mg} / \mathrm{ml}), 2.5 \%(25 \mathrm{mg} / \mathrm{ml}), 1.25 \%(12.50 \mathrm{mg} /$ $\mathrm{ml}), 0.625 \%(6.25 \mathrm{mg} / \mathrm{ml}), 0.3125 \%(3.125 \mathrm{mg} / \mathrm{ml})$ and $0.156 \%(1.56 \%)$ were $1.84,3.95,16.94,23.78,71.10$ and $88.29 \%$, respectively with corrected hatching percentage $2.17,4.28,17.28,24.11,71.43$ and $88.63 \%$, respectively. $B$. frondosa aqueous extract gave $\mathrm{ED}_{50}$ value $0.463 \mathrm{mg} / \mathrm{ml}$ with lower and upper confidence limit $0.276 \mathrm{mg} / \mathrm{ml}$ and $0.683 \mathrm{mg} / \mathrm{ml}$, respectively, and methanolic extract gave $\mathrm{ED}_{50}$ value $0.453 \mathrm{mg} / \mathrm{ml}$ with lower and upper limit 0.299 $\mathrm{mg} / \mathrm{ml}$ and $0.638 \mathrm{mg} / \mathrm{ml}$, respectively.

\section{Larval paralysis test}

In larval paralysis test, aqueous extract at 10\% (100 mg/ $\mathrm{ml}$ ) concentration showed $86.75 \%$ efficacy with corrected percentage efficacy $84.44 \%$, however, at $5 \%(50 \mathrm{mg} / \mathrm{ml})$, $2.5 \%$ (25 mg/ml), $1.25 \%$ (12.5 mg/ml), 0.625\% (6.25 $\mathrm{mg} / \mathrm{ml}), 0.312 \%(3.12 \mathrm{mg} / \mathrm{ml})$ and $0.156 \%(1.56 \mathrm{mg} /$ $\mathrm{kg}$ ) concentration, percentages efficacy were $74.33 \%$, $70.67 \%, 53.0 \%, 19.0 \%, 14.29 \%$ and $9.36 \%$, respectively with corrected percentage efficacy $72.00,68.33,50.67$, $16.67,11.96$ and $7.02 \%$, respectively. Whereas, at $10 \%$ $(100 \mathrm{mg} / \mathrm{ml})$ concentration, methanolic extract showed $97.33 \%$ effectiveness with $95 \%$ corrected efficacy. However, at $5 \%(50 \mathrm{mg} / \mathrm{ml}), 2.5 \%(25 \mathrm{mg} / \mathrm{ml}), 1.25 \%$ $(12.5 \mathrm{mg} / \mathrm{ml}), 0.625 \%(6.25 \mathrm{mg} / \mathrm{ml}), 0.3125 \% \quad(3.125$ $\mathrm{mg} / \mathrm{ml})$ and $0.156 \%(1.56 \mathrm{mg} / \mathrm{ml})$ concentration, efficacy percentages were $89.00,78.00,69.67,38.08,18.71$ and $17.1 \%$, respectively with corrected efficacy $95.00,86.60$, 
$75.67,67.33,35.76,16.45$ and $14.84 \%$, respectively. $B$. frondosa aqueous extract gave $\mathrm{ED}_{50} 1.607 \mathrm{mg} / \mathrm{ml}$ with lower and upper limit $1.139 \mathrm{mg} / \mathrm{ml}$ and $2.282 \mathrm{mg} / \mathrm{ml}$, respectively, and methanolic extract gave $\mathrm{ED}_{50} 0.854 \mathrm{mg} /$ $\mathrm{ml}$ with lower and upper limit $0.652 \mathrm{mg} / \mathrm{ml}$ and $1.098 \mathrm{mg}$ / $\mathrm{ml}$, respectively.

\section{Adult mortality test}

The results of aqueous and methanolic extract showed $100 \%$ mortality of adult worm at $10 \%(100 \mathrm{mg} / \mathrm{ml})$ and $5 \%(50 \mathrm{mg} / \mathrm{ml})$ concentration with corrected mortality $100 \%$. Whereas, aqueous extract at $2.5 \%(25 \mathrm{mg} / \mathrm{ml})$, $1.25 \%(12.5 \mathrm{mg} / \mathrm{ml}), 0.625 \%(6.25 \mathrm{mg} / \mathrm{ml}), 0.3125 \%$ $(3.125 \mathrm{mg} / \mathrm{ml})$ and $0.156 \%(1.56 \mathrm{mg} / \mathrm{ml})$ concentration showed $100 \%, 70 \%, 33 \%, 0 \%$ and $0 \%$ mortality, respectively with corrected mortality $100 \%, 70 \%, 33 \%$, $0 \%$ and $0 \%$, respectively. While methanolic extract at $2.5 \%(25 \mathrm{mg} / \mathrm{ml}), 1.25 \%(12.5 \mathrm{mg} / \mathrm{ml}), 0.625 \%(6.25$ $\mathrm{mg} / \mathrm{ml}), 0.3125 \%(3.125 \mathrm{mg} / \mathrm{ml})$ and $0.156 \%(1.56 \mathrm{mg} /$ $\mathrm{ml}$ ) concentration showed $100 \%, 100 \%, 100 \%, 33 \%$ and $20 \%$ mortality, respectively with corrected mortality $73 \%$, $67 \%, 57 \%, 60 \%$ and $37 \%$, respectively. The aqueous extract of $B$. frondosa gave $57.57 \%$ average corrected mortality and methanolic extract gave $72.00 \%$ average corrected mortality. B. frondosa gave $64.79 \%$ overall per cent corrected mortality.

\section{In-vivo evaluation of anthelmintic activity}

The result of in-vivo test revealed that on $7^{\text {th }}$ day post infection the mean EPG of aqueous extract treated group I increased to $912.5 \pm 363.73$ from $812.5 \pm 172.62$ whereas, in the methanolic extract treated group II decreased to $837.5 \pm 239.00$ from $937.5 \pm 223.56$, respectively. However, mean EPG on the $14^{\text {th }}$ day reduced in both group I (200.0 \pm 68.14$)$ and group II $(375.0 \pm 161.19)$. Whereas, in group I mean EPG on $21^{\text {st }}$ and $28^{\text {th }}$ day was $375.0 \pm 92.10$ and $525.0 \pm 170.87$, respectively and in case of a group II mean EPG on $21^{\text {st }}$ and $28^{\text {th }}$ day was $875.0 \pm 169.82$ and $762.5 \pm 162.50$, respectively (Table 1 ). While fecal egg count reduction $\%$ in group I on $7^{\text {th }}, 14^{\text {th }}, 21^{\text {st }}$ and $28^{\text {th }}$ day were recorded as 10.98, 73.33, 20.00 and 32.79\%, respectively. The highest and significant reduction $(p<0.01)$ was observed on day $14^{\text {th }}(73.33 \%)$. However, fecal egg count reduction $\%$ in group II on $7^{\text {th }}, 14^{\text {th }}, 21^{\text {st }}$ and $28^{\text {th }}$ day were recorded as $18.29,50.00,57.14$, and
$31.15 \%$, respectively. The highest and significant reduction $(\mathrm{p}<0.05)$ was recorded on the $21^{\text {st }}$ day $(57.14 \%)$ (Table 2$)$.

The results indicated that $B$. frondosa possess anthelmintic activity against benzimidazole resistant GI nematodes. The findings are in agreement with the previously published research works (Iqbal et al., 2006; Sant et al., 2014; Singh et al., 2015). In egg hatch assay, both the aqueous and methanolic extracts of $B$. frondosa at $5 \%$ and above concentration showed higher inhibition of egg hatching compared to low concentration. Similar dose-dependent egg hatching inhibitions were evaluated using the aqueous and methanolic extract of Allium sativum, Ocimum sanctum and Eucalyptus globulus on naturally occurring GI nematodes of sheep (Kanojiya et al., 2015a; Kanojiya et al., 2015b; Kanojiya et al., 2015c). Similar findings were reported by Eguale et al. (2007) that aqueous and hydro-alcoholic extracts of Coriandrum sativum extracts inhibited hatching of eggs completely at concentration of less than $0.5 \mathrm{mg} / \mathrm{ml}$. The possible mechanism of inhibition could be due to the presence of a high concentration of phenolic, flavonoids and tannin and other secondary metabolites content in the seeds of Butea spp. to inhibit the hatching of nematode eggs (Carvalho et al., 2012; Sant et al., 2014; Singh et al., 2015).

In the larval paralysis test, results indicated that aqueous extract of $B$. frondosa at $100 \mathrm{mg} / \mathrm{ml}$ concentration showed $86.75 \%$ efficacy with corrected percentage efficacy $84.44 \%$, and methanolic extract showed $97.33 \%$ efficacy with corrected efficacy $95.0 \%$. Similar to egg hatch tests, the larval paralysis test also followed a dose-dependent trend. Our findings were relatively in agreement with Kanojiya et al. (2015a) who reported that the aqueous extract and methanolic extract of Allium sativum on naturally occurring GI nematodes of sheep showed 100\% paralysis of $3^{\text {rd }}$ stage larvae at $100 \mathrm{mg} / \mathrm{ml}$ concentration. Similar efficacy has also been reported by Kamaraj et al. (2011) and Akhtar et al. (2015). This difference in efficacy might be due to variation in the active principles of these plants.

In the adult mortality test, the aqueous and methanolic extract of seeds of $B$. frondosa showed $100 \%$ mortality at $100 \mathrm{mg} / \mathrm{ml}$ and $50 \mathrm{mg} / \mathrm{ml}$ concentrations. Singh et al. (2015) reported that aqueous extract of seeds of $B$. monosperma was responsible for complete mortality of $H$. contortus at same concentrations. Similar findings 
Table 1: In-vivo anthelmintic efficacy of Butea frondosa extracts against gastrointestinal nematode in goat

\begin{tabular}{|c|c|c|c|c|c|c|}
\hline \multirow{2}{*}{ Groups } & \multirow{2}{*}{$\begin{array}{l}\text { Treatment @ } 100 \mathrm{mg} / \mathrm{kg} \text { b. wt. } \\
\text { orally on } 0,3^{\text {rd }} \& 7^{\text {th }} \text { day }\end{array}$} & \multicolumn{5}{|c|}{ Mean EPG } \\
\hline & & Day 0 & Day 7 & Day 14 & Day 21 & Day 28 \\
\hline Group I & B. frondosa aqueous extract & $812.5 \pm 172.62$ & $912.5 \pm 363.73$ & $200.0 \pm 68.14$ & $700.0 \pm 217.12$ & $512.5 \pm 219.12$ \\
\hline Group II & B. frondosa methanolic extract & $937.5 \pm 223.56$ & $837.5 \pm 239.00$ & $375.0 \pm 161.19$ & $375.0 \pm 92.10$ & $525.0 \pm 170.87$ \\
\hline Group III & Untreated Control & $962.5 \pm 230.63$ & $1025.0 \pm 209.38$ & $750.0 \pm 137.58$ & $875.0 \pm 169.82$ & $762.5 \pm 162.50$ \\
\hline
\end{tabular}

Table 2: Faecal egg count reduction per cent of different groups

\begin{tabular}{llllll}
\hline \multirow{2}{*}{ Groups } & Treatment & \multicolumn{3}{c}{ FECRT \% } \\
\cline { 3 - 5 } & Bay 7 & Day 14 & Day 21 & Day 28 \\
\hline Group I & B. frondosa aqueous extract & 10.98 & $73.33^{* *}$ & 20.00 & 32.79 \\
Group II & B. frondosa methanolic extract & 18.29 & 50.00 & $57.14^{*}$ & 31.15 \\
\hline
\end{tabular}

Significant $* * \mathrm{p}<0.01,{ }^{*} \mathrm{p}<0.05$.

have also been documented by various researchers like Kalesaraj and Kurup (1962) who reported alkaloid hydrochlorides extracted from seeds of $B$. frondosa to be $100 \%$ lethal to earthworms within $24 \mathrm{hrs}$. Mansoor et al. (2013) reported that crude methanolic extract of $B$. frondosa seed showed significant anthelmintic activity on earthworm (Lumbricus terrestris), the extract exhibited $100 \%$ mortality of worms at $50 \mathrm{mg} / \mathrm{ml}$ concentration. Prashanth et al. (2001) reported the efficacy of methanolic extract of $B$. frondosa against adult $H$. contortus. These findings could be due to palasonin in Palash seed and having anthelmintic activity. Palasonin inhibited the glucose uptake and depleted the glycogen content in the presence of glucose indicating that palasonin affects the energy-generating mechanism of the parasite. It also significantly increased lactic acid suggesting inhibition of ATP production. Therefore, palasonin may act via either inhibition of energy metabolism and/ or alteration in the motor activity of the parasite (Kumar et al., 1995; Mali and Mehta, 2008).

The results of in vivo assay revealed that aqueous extract of $B$. frondosa seeds showed the highest $(73.33 \%)$ and significant $(p<0.01)$ reduction of egg per gram of faeces recorded on $14^{\text {th }}$ day post-treatment whereas, the methanolic extract showed the highest $(57.14 \%)$ and significant $(\mathrm{p}<0.05)$ reduction recorded on $21^{\text {st }}$ day posttreatment. No evidence of toxicity was recorded on the experimental doses during or after the treatment. A similar observation has been recorded by Iqbal et al. (2006) who reported the crude powder of $B$. monosperma seeds showed a maximum reduction of $78.4 \%$ in eggs per gram of faeces on $10^{\text {th }}$ day post-treatment which was maintained till day $14^{\text {th }}$ with the dose of $3 \mathrm{~g} / \mathrm{kg}$. Al-Shaibani et al. (2009) revealed that ethanolic and aqueous extracts of Fumaria parviflora showed the highest reduction of egg per gram of faeces recorded on $14^{\text {th }}$ day post treatment with the dose of $200 \mathrm{mg} / \mathrm{kg}$ body weight. This difference in efficacy might be due to variation in the active principles of these plants.

\section{CONCLUSION}

The results of the present study indicated that both the aqueous and methanolic extract of $B$. frondosa possess anthelmintic activity against different stages of GI nematodes of goats as evident by the in-vitro and invivo studies, however, the performance of methanolic extract was better than that of aqueous extract. Therefore, $B$. frondosa could be considered as an alternative to the chemical anthelmintic.

\section{ACKNOWLEDGEMENTS}

The authors wish to express gratitude to the Dean, College of Veterinary Science \& Animal Husbandry, Jabalpur and Vice Chancellor, Nanaji Deshmukh Veterinary Science University (NDVSU), Jabalpur for providing all necessary facilities during the entire course of the study. 


\section{REFERENCES}

Akhtar, S., Dey, A.R., Hossain, S., Dey, T.R. and Begum, N. 2015. In-vitro anthelmintic effect of some medicinal plants against Haemonchus contortus. J. Anim. Sc. Adv., 5: 11621170.

Al-Shaibani, I.R.M., Phulan, M.S. and Shiekh, M. 2009. Anthelmintic activity of Fumaria parviflora (Fumariaceae) against gastrointestinal nematodes of sheep. Int. J. Agric. Biol., 11: 431-436.

Carvalho, C.O., Chagas, A.C.S., Cotinguiba, F., Furlan, M., Brito, L.G., Chaves, F.C., Stephan, M.P., Bizzo, H.R. and Amarante, A.F. 2012. The anthelmintic effect of plant extracts on Haemonchus contortus and Strongyloides venezuelensis. Vet. Parasitol., 183: 260-280.

Coles, G.C., Bauer, C., Borgsteede, F.H., Geerts, S., Klei, T.R., Taylor, M.A. and Waller, P.J. 1992. World Association for the Advancement of Veterinary Parasitology (WAAVP) methods for the detection of anthelmintic resistance in nematodes of veterinary importance. Vet. Parasitol., 44: 35-44.

Das, G., Dixit, A.K., Nath, S., Agrawal, V. and Dongre, S. 2015. Levamisole and fenbendazole resistance among gastrointestinal nematodes in goats at Jabalpur, Madhya Pradesh. J. Vet. Parasitol., 29: 98-102.

Dash, K. M., Hall, E., \& Barger, I. A. 1988. The role of arithmetic and geometric mean worm egg counts in faecal egg count reduction tests and in monitoring strategic drenching programs in sheep. Australian Vet. J., 65: 66-68.

Dixit, A.K., Das, G., Dixit, P., Singh, A.P., Kumbhakar, N.K., Sankar, M. and Sharma, R.L. 2017. An assessment of benzimidazole resistance against caprine nematodes in Central India. Trop. Anim. Health Prod., 49: 1471-1508.

Eguale, T., Tilahun, G., Debella, A., Feleke, A., and Makonnen, E. 2007. In vitro and in vivo anthelmintic activity of crude extracts of Coriandrum sativum against Haemonchus contortus. J. Ethnopharmacol., 110: 428-433.

Finney, D.J.1971. Probit analysis, $3^{\text {rd }}$ Edn., Cambridge University Press, Cambridge.

Iqbal, Z., Lateef, M., Jabbar, A., Ghayur, M.N. and Gilani, A.H. 2006. In vivo anthelmintic activity of Butea monosperma against Trichostrongylid nematodes in sheep. Fitoterapia., 77: $137-40$.

Kalesaraj, R. and Kurup, P.A. 1962. Investigation on the anthelmintic principle of Butea frondosa seeds. Indian $J$. Pharm., 24: 63-65.

Kamaraj, C., Rahuman, A.A., Elango, G., Bagavan, A. and Zahir, A.A. 2011. Anthelmintic activity of botanical extracts against sheep gastrointestinal nematodes, Haemonchus contortus. Parasitol. Res., 109: 37-45.
Kanojiya, D., Shanker, D., Sudan, V., Jaiswal, A. K., and Parashar, R. 2015a. Assessment of in vitro and in vivo anthelminthic potential of extracts of Allium sativum bulb against naturally occurring ovine gastrointestinal nematodiosis. Vet. Q., 35: 200-206.

Kanojiya, D., Shanker, D., Sudan, V., Jaiswal, A. K., and Parashar, R. 2015b. Anthelmintic activity of Ocimum sanctum leaf extract against ovine gastrointestinal nematodes in India. Res. Vet. Sc., 99: 165-170.

Kanojiya, D., Shanker, D., Sudan, V., Jaiswal, A.K. and Parashar, R. 2015c. In vitro and in vivo efficacy of extracts of leaves of Eucalyptus globulus on ovine gastrointestinal nematodes. Parasitol. Res., 114: 141-148.

Kumar, D., Mishra, S.K. and Tripathi, H.C. 1995. Possible mechanism of anthelmintic action of palasonin on Ascaridia galli. Indian J. Pharmacol., 27: 161-166.

Mali, R.G. and Mehta, A.A. 2008. A Review on Anthelmintic Plants. Nat. Prod. Rad., 7: 466-475.

Mansoor, A., Sharif, H., Alam, S.M., Mehjabeen, J.N. and Sherwani, S.K. 2013. Standardization and toxicological studies of Butea frondosa methanolic seeds extract. Am. J. Res. Commun., 1: 42-55.

Patil, M.V., Pawar, S. and Patil, D.A. 2006. Ethnobotany of Butea monosperma (Lam.) Kuntze in North Maharashtra, Indian Nat. Prod. Rad., 5: 323-325.

Prashanth, D., Asha, M.K., Amit, A. and Padmaja, R. 2001. Anthelmintic activity of Butea monosperma. Fitoterapia., 72: 421-422.

Sant, A., Ingole, A., Dhabarde, D. and Kamble, M. 2014. Evaluation of anthelmintic activity of flower extract of Butea monosperma var. lutea. J. Pharmacogn. Phytochem., 2: 152153.

Singh, G., Singh, R., Verma, P.K., Singh, R. and Anand, A. 2015. Anthelmintic efficacy of aqueous extract of Butea monosperma (Lam.) Kuntze against Haemonchus contortus of sheep and goats. J. Parasit. Dis., 39: 200-205.

Sloss, M.W., Kemp, R.L. and Zajac, A.M. 1997. Veterinary Clinical Parasitology, $6^{\text {th }}$ Edn. International Book Distributing Co., Lucknow, pp. 198.

Snedecor, G.W. and Cochran, W.G. 1994. Statistical Methods, 7th Edn., Oxford and IBH Publishing Co., New Delhi, pp. $1-593$.

Soulsby, E.J.L. 1982. Helminths. Arthropods and Protozoa of domesticated animals. 7th ed. Baillière Tindall, London, pp. 291.

Sujon, M.A., Mostofa, M., Jahan, M.S., Das, A.R. and Rob, S. 2008. Study on medicinal plant against gastrointestinal nematode of goat. Bangladesh J. Vet. Med., 6: 179-183. 
Tandon, V., Yadav, A.K., Roy, B. and Das, B. 2011. Phytochemicals as cure of worm infections in traditional medicine systems. Emerging trends in zoology. Narendra Publishing House, New Delhi, pp. 51-378.

Temesgen, Z. and Tone, T. 2019. A Review of Anthelmintic Resistance in Domestic Animals. Acta Parasitol. Globalis., 10: $117-128$.
Verma, R., Lata, K. and Das, G. 2018. An overview of anthelmintic resistance in gastrointestinal nematodes of livestock and its management: India perspectives. Int. J. Chem. Stud., 6: 1755-1762.

Vohra, S., Singh, S. and Sangwan, A.K. 2019. Cross Anthelmintic Resistance in Goats of Unorganized Sector in Haryana. $J$. Anim. Res., 9: 715-720. 
